\title{
PIRMINIŲ SVEIKATOS PRIEŽIŪROS İSTAIGŲ DARBUOTOJŲ POŽIŪRIS İ STRATEGINIO VALDYMO ELEMENTŲ IR VEIKLOS RODIKLIŲ SĄSAJAS
}

\author{
Linas Šablinskas, Gintautas Cibulskas \\ Lietuvos sveikatos moksly universitetas
}

\begin{abstract}
Raktažodžiai: pirminès sveikatos priežiūros ịstaigos, sveikatos priežiūros darbuotojai, strateginio valdymo elementai, veiklos rodikliai.
\end{abstract}

\section{Santrauka}

Tikslas - ịvertinti pirminių sveikatos priežiūros ịstaigų darbuotojų požiūrị ị strateginio valdymo elementų ir veiklos rodiklių sąsajas.

Tyrimo metodika. Tyrimas atliktas 2016 metais, taikant kiekybinị (anketinè apklausa) ir kokybini (pusiau struktūruoto interviu metodas) tyrimo metodus. Anketinè apklausa taikyta apklausti dviejų skirtingo tipo pirminių sveikatos priežiūros ịstaigų darbuotojams. Remiantis apklausos duomenimis, parengti interviu klausimai tụ pačių sveikatos priežiūros įstaigų vadovams. Statistinė duomenų analizè atlikta naudojant IBM SPSS 22.0 statistinès analizès paketą, grafikų ir lentelių kūrimui buvo naudojama Microsoft Excel 2010.

Rezultatai ir išvados. Sveikatos priežiūros darbuotojų ir vadovų nuomonès vertinimo rezultatai atskleidè, kad ìstaigos darbuotojų įtraukimas ị strateginio valdymo elementų formavimą ir informuotumas strateginių siekių kontekste turi didelès ịtakos pirminių sveikatos priežiūros ịstaigų pacientų skaičiaus mažèjimo arba didèjimo rodikliams. Aiškus darbuotojų užduočių išgryninimas strateginių siekių kontekste, savo svarbos siekiant strateginių tikslų pajauta, realizuojant ịstaigos misiją, taip pat turi ịtakos pirminių sveikatos priežiūros ịstaigų pacientų skaičiaus mažejimo arba didèjimo rodikliams. Didžiausią įtaką, darbuotojų ir vadovų nuomone, šiems veiklos rodikliams daro šeimos gydytojai. Darbuotojų įtraukimas i strateginių valdymo elementų kūrimą turi didelès ịtakos minètų veiklos rodiklių augimui.

\section{Ivadas}

Lietuvos sveikatos priežiūros įstaigos pagal teikiamas paslaugas skirstomos ị atitinkamus lygmenis. Toks skirs- tymas leidžia sutaupyti lèšų, tikintis, kad didžioji dalis (80 proc.) sveikatos problemų bus išspręsta pirmines sveikatos priežiūros paslaugas teikiančiose įstaigose [4]. Valstybinių ir privačiujų pirminių sveikatos priežiūros ịstaigų konkurencija skatina peržiūrèti išsikeltus tikslus, veiklos rodiklius, žmogiškuosius išteklius ir kitus strateginio valdymo elementus. Strategija - tai visapusiškas planas, skirtas padèti organizacijai igyvendinti misiją ir užsibrèžtus tikslus [6]. Strategijos sudedamosios dalys apima tris pagrindinius elementus: organizacijos veiklos kryptị, tikslus ir išteklius, reikalingus tiems tikslams igyvendinti [2]. Visgi, strategija gali būti suprantama ir kaip siekis pergudrauti konkurentus. Yra daug strategijos apibrèžimų ir nèra vieno teisingo, nors dažniausiai strategija kuriama aukščiausiame valdymo lygmenyje ir apibrèžia pagrindinius organizacijos tikslus, misiją, viziją. Svarbu, kad organizacijos strateginio valdymo naudą, savo misiją ịgyvendinant strategiją suvoktų ne tik aukščiausio, bet ir bet kokio lygmens darbuotojai [6].

Sveikatos priežiūros įstaigose vienas iš svarbių strateginių išteklių yra žmogiškieji ištekliai, kuriems turètų būti skiriama daugiau dèmesio, siekiant greičiau, kokybiškiau igyvendinti išsikeltus pagrindinius ịstaigos tikslus ir uždavinius - organizacijos strategiją [1,9]. Svarbu įvertinti sveikatos priežiūros ịstaigų darbuotojų požiūrị i pagrindinius strateginio valdymo elementus, savęs suvokimą strategijos kūrimo ir įgyvendinimo kontekste bei pagrindinių strateginio valdymo elementų įtaką svarbiausiems pirminių sveikatos priežiūros įstaigų veiklos rodikliams (šiuo atveju - pacientų skaičiaus mažèjimui arba didejjimui).

Darbo tikslas - įvertinti pirminių sveikatos priežiūros įstaigų darbuotojų požiūrị ị strateginio valdymo elementų ir veiklos rodiklių sąsajas.

\section{Tyrimo medžiaga ir metodai}

Tyrimas buvo atliekamas 2016 metais dviejose iš didžiausių skirtingo tipo (valstybineje ir privačioje) Kauno rajono pirminès sveikatos priežiūros ịstaigų. Tyrimą sudarè du eta- 
pai. Pirmojo etapo metu buvo vykdoma anketinè apklausa (kiekybinis tyrimo metodas), kurioje dalyvavo 119 sveikatos priežiūros įstaigų darbuotojų: 98 valstybinès ir 21 - privačios. Anketa parengta remiantis atlikta mokslinès literatūros analize. Siekiant iqvertinti klausimyno tinkamumą, buvo atliktas žvalgomasis tyrimas, kuriame dalyvavo po du tiriamujų įstaigų darbuotojus. Pagal išsakytus pastebejimus, anketa buvo koreguojama. Anketa sudaryta iš 94 uždaro tipo klausimų, suskirstytų ị 5 klausimų blokus. Siekta nustatyti pirminių sveikatos priežiūros ịstaigų darbuotojų požiūrị ị strateginio valdymo elementų ir veiklos rodiklių sąsajas. Antrojo etapo metu buvo taikomas pusiau struktūruoto interviu metodas (kokybinis tyrimo metodas). Antrajame etape dalyvavo anksčiau minètų pirminių sveikatos priežiūros ịstaigų vadovai-ekspertai, kurie anketineje apklausoje nedalyvavo. Interviu klausimai buvo sudaryti remiantis anketinès apklausos metu gautais rezultatais. Interviu buvo siekiama atskleisti vadovų ekspertinị požiūrị ị darbuotojų apklausos metu gautus rezultatus. Anketinès apklausos duomenu analizei buvo naudojamas IBM SPSS 22.0 statistinès analizès paketas, grafiku ir lenteliu kūrimui - Microsoft Excel 2010. Dviem priklausomoms imtims palyginti taikytas Wilcoxon kriterijus, nepriklausomoms Mann-Whitney kriterijus. Kiekybiniai duomenys pateikiami procentais. Interviu duomenims apdoroti buvo taikomas turinio analizès metodas.

\section{Rezultatai}

Pirminių sveikatos priežiūros ịstaigų darbuotojų nuomone, stiprybių, silpnybių, galimybių ir grèsmių (SSGG) elementų ịtaka svarbi pacientų skaičiaus didejjimui. Palankiai vertinusių šių elementų svarbą procentinis pasiskirstymas buvo tarp 60,5 ir 82,4 procento. Darbuotojų nuomone, pacientų prisirašymui svarbesni tie elementai, kurie atspindi teigiamas ịstaigos puses. Darbuotojai geriau turètų žinoti įstaigos stiprybes ir galimybes, jas viešinti. Tai gali būti svarbūs strateginiai elementai veiklos rodiklių augimui (1 pav.).

Didžioji dalis (62,9 proc.) pirminių sveikatos priežiūros įstaigų darbuotojų mano, kad darbuotojų įstaigos stiprybių neišmanymas gali paskatinti pacientų skaičiaus mažejimą, o 60 proc. mano, kad tai turi ịtakos pacientų išsirašymui (veiklos rodiklių blogèjimui) (2 pav.).

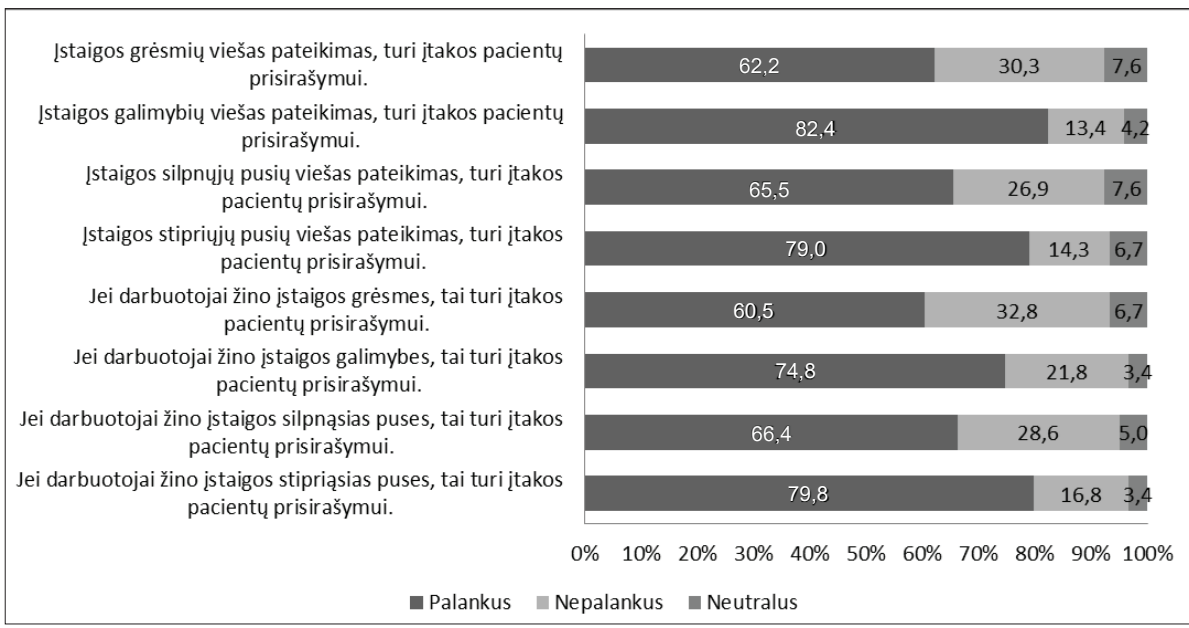

1 pav. Darbuotojų nuomonė apie SSGG elementų viešinimo įtaką pacientų prisirašymui

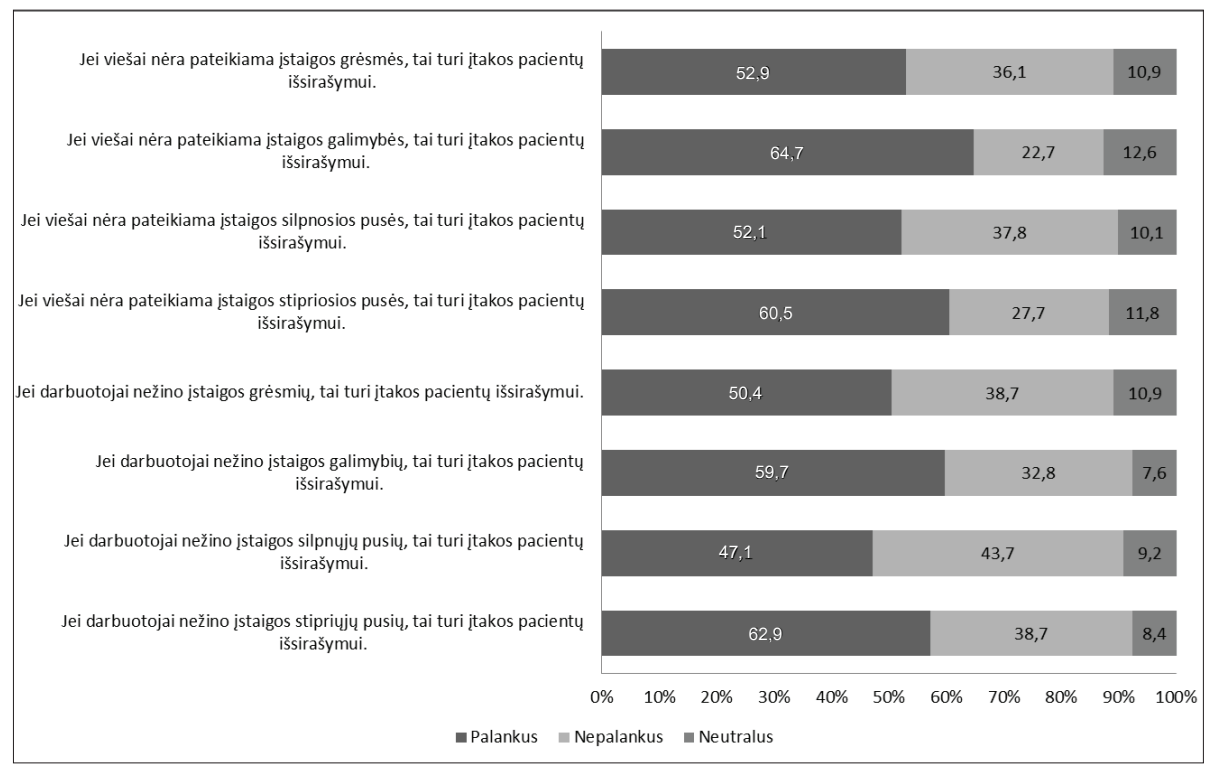

2 pav. Darbuotojų nuomonè apie SSGG elementų viešinimo įtaką pacientų išsirašymui 
Respondentų nuomone, labai svarbus yra misijos (71,4 proc.) ir vizijos ( 73,9 proc.) paviešinimas, tai yra parodymas, ką įstaiga daro ir ko ji siekia. Tai svarbiausi elementai, turintys įtakos pacientų skaičiaus didejjimui. Jei pacientai žino, kokie yra ịstaigos prioritetai dabar ir kokia ịstaiga siekia būti ateityje, tai gali nulemti apsisprendimą prisirašyti vienoje ar kitoje sveikatos priežiūros įstaigoje (3 pav.).

Jeigu sveikatos priežiūros ịstaiga neturi savo misijos (61,3 proc.), vizijos $(55,5$ proc.) arba jų viešai nepaskelbia, tai, darbuotojų nuomone, gali neigiamai paveikti veiklos rodiklius, - paskatinti išsirašyti daugiau pacientų (4 pav.).

Sveikatos priežiūros įstaigos, darbuotojų nuomone, turètų paviešinti ir tokius elementus, kaip istaigos tikslai $(74,8$ proc.) ir uždaviniai ( 73,9 proc.), kurie taip pat parodo

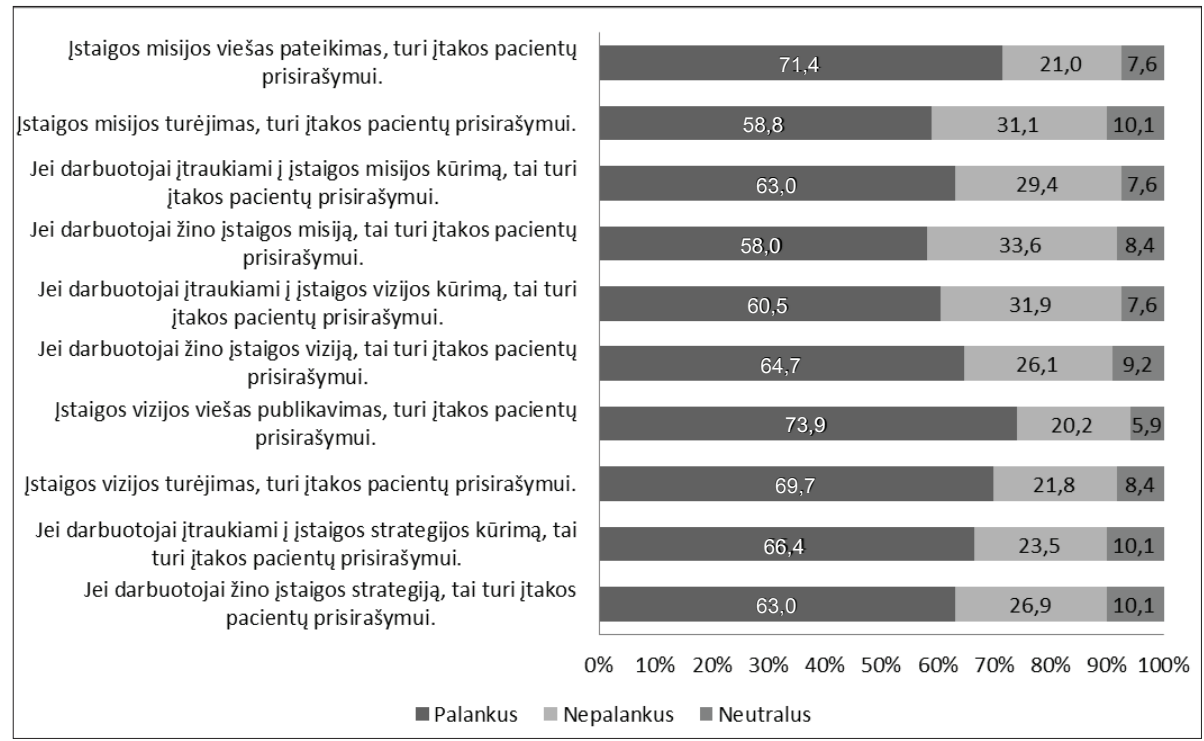

3 pav. Darbuotojų nuomonė apie misijos, vizijos ir strategijos elementų viešinimo ịtaką pacientų prisirašymui

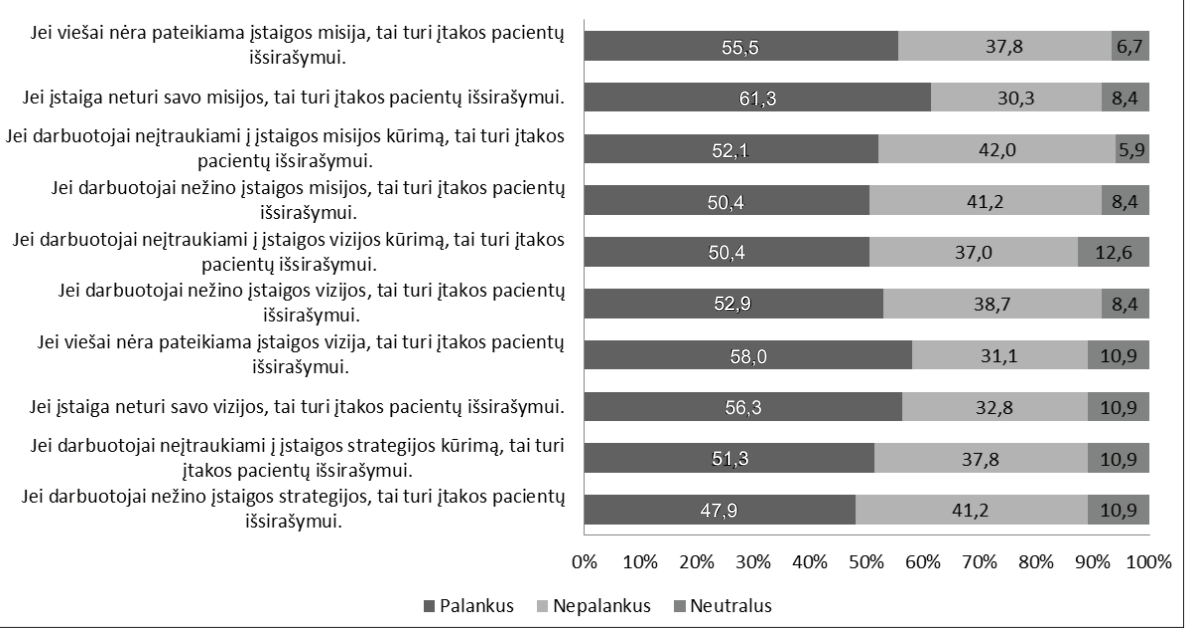

4 pav. Darbuotojų nuomonè apie misijos, vizijos ir strategijos elementų viešinimo įtaką pacientų išsirašymui istaigos siekius ir prioritetus ir gali turèti teigiamos ịtakos pacientų skaičiaus augimui (5 pav.).

Nustatyta, kad 63,9 proc. apklaustujų mano, kad įstaigos darbuotojų užduočių neišmanymas gali paskatinti išsirašyti daugiau pacientų. Galima daryti prielaidą, kad savo darbo užduočių neišmanymas gali sukelti papildomos sumaišties ìstaigos darbe, kuri turès įtakos pacientų neigiamam įstaigos vertinimui. Vadinasi, darbuotojams svarbu žinoti savo užduotis įstaigos tikslų kontekste, o išorinès aplinkos vertinimas igalins išvengti netikètumų ir pacientų skaičiaus mažejimo (61,3 proc.), (6 pav.).

Ivertinus apklausos dalyvių nuomonę, nustatyta, kad dažniau ị įstaigos valdymą ịtraukiami gydytojai (44,4 proc.), kurie dažnai yra ir kaip administracijos darbuotojai, mažiausiai - pagalbinis personalas $(4,3$ proc.). Atlikto interviu metu nustatyta, kad labiausiai i ịstaigos valdymą turètų būti ịtraukti šeimos gydytojai (valstybinès istaigos vadovo nuomone) ir administracijos darbuotojai (privačios ịstaigos vadovo nuomone).

Darbuotojai, turintys vadybinio darbo patirties, statistiškai reikšmingai dažniau įtraukiami ị ịstaigos valdymą, nei jos neturintys $(p \leq 0,001)$. Galima manyti, kad pirminiu sveikatos priežiūros ịstaigų vadovai, įtraukdami darbuotojus i i istaigos valdymą, atsižvelgia i ankstesnius darbuotojo vadybinius ịgūdžius.

Daugiau kaip pusè $(52,4$ proc.) privačios ir tik 20,4 proc. valstybinès pirminès sveikatos priežiūros įstaigos darbuotojų 
jaučiasi įtraukiami i i istaigos valdymą, nors ši statistiškai reikšmingą skirtumą galèjo lemti ir skirtingas apklausoje dalyvavusių darbuotojų skaičius $(\mathrm{p} \leq 0,005)$.

Darbuotojų itraukimas i i istaigos valdymą gali turèti teigiamos įtakos ístaigos veiklos rodikliams, tačiau mūsų tyrime nustatyta, kad privačioje įstaigoje 47,6 proc. darbuotojų jaučiasi neįtraukiami ị ịstaigos valdymą, o valstybinèje šis skaičius sudaro net 79,6 procentus. Tai patvirtina ir kitų autorių atliktas tyrimas, kuriame nustatyta, kad 45,8 proc. sveikatos priežiūros ịstaigų darbuotojų jaučiasi neịtraukiami ị ịstaigos valdymą [7].

Atlikto tyrimo rezultatai parodè, kad sveikatos priežiūros darbuotojų nuomone, didžiausią itaką pacientų prisirašymui daro gydytojai $(77,8$ proc.) ir slaugytojai (71,7 proc.), o mažiausią - pagalbinis personalas $(26,1$ proc.). Tai patvirtino ir sveikatos priežiūros ịstaigų vadovai. Tokie rezultatai gali būti dèl to, kad sveikatos priežiūros specialistai daugiausia dirba tiesiogiai su pacientu.

Žmogiškujų išteklių svarbą sveikatos priežiūros įstaigų veiklos rodikliams patvirtina kitas tyrimas, kuriame nustatyta, kad 81 proc. pacientu pasitiki gydančiuoju gydytoju, tai reiškia, kad pacientams svarbi gydytojo nuomone ir jo teikiama informacija [5].

Pusiau struktūruoto interviu su pirminių sveikatos priežiūros isstaigų vadovais duomenų analizè atskleidè, kad svarbiausias strateginio valdymo elementas, jų nuomone, yra įstaigos tikslas, tačiau ịvardijant antrą pagal svarbumą elementą, nuomonès

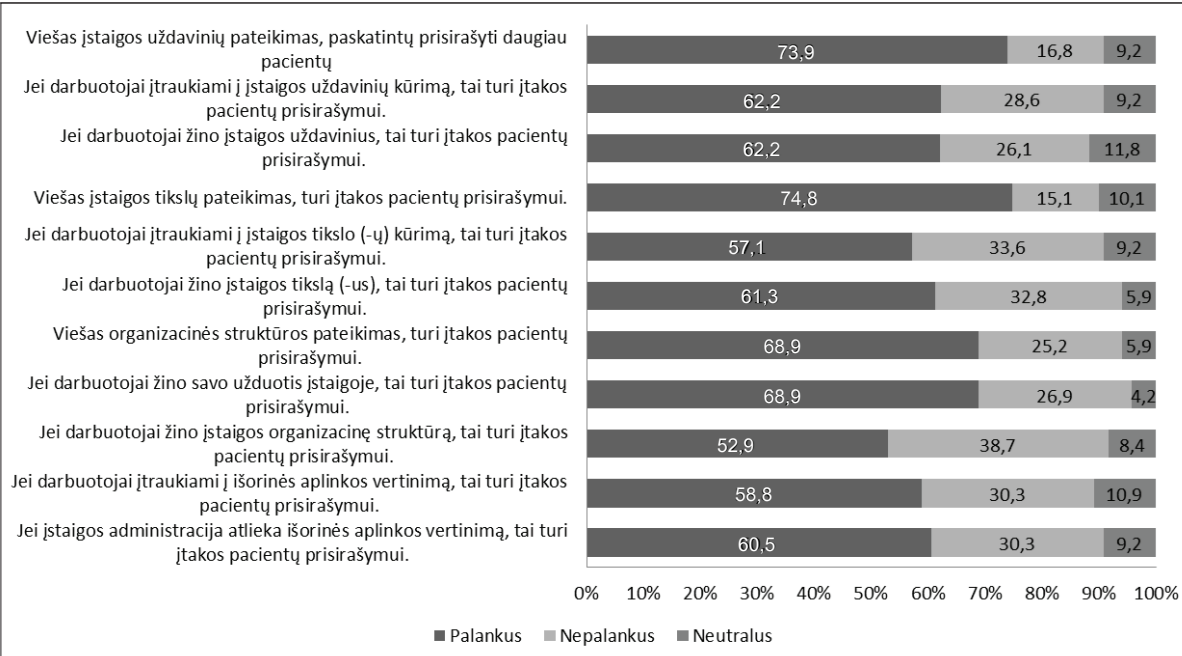

5 pav. Darbuotojų nuomonè apie tikslų, uždavinių, užduočių, organizacinės struktūros ir aplinkos vertinimo elementų įtaką pacientų prisirašymui

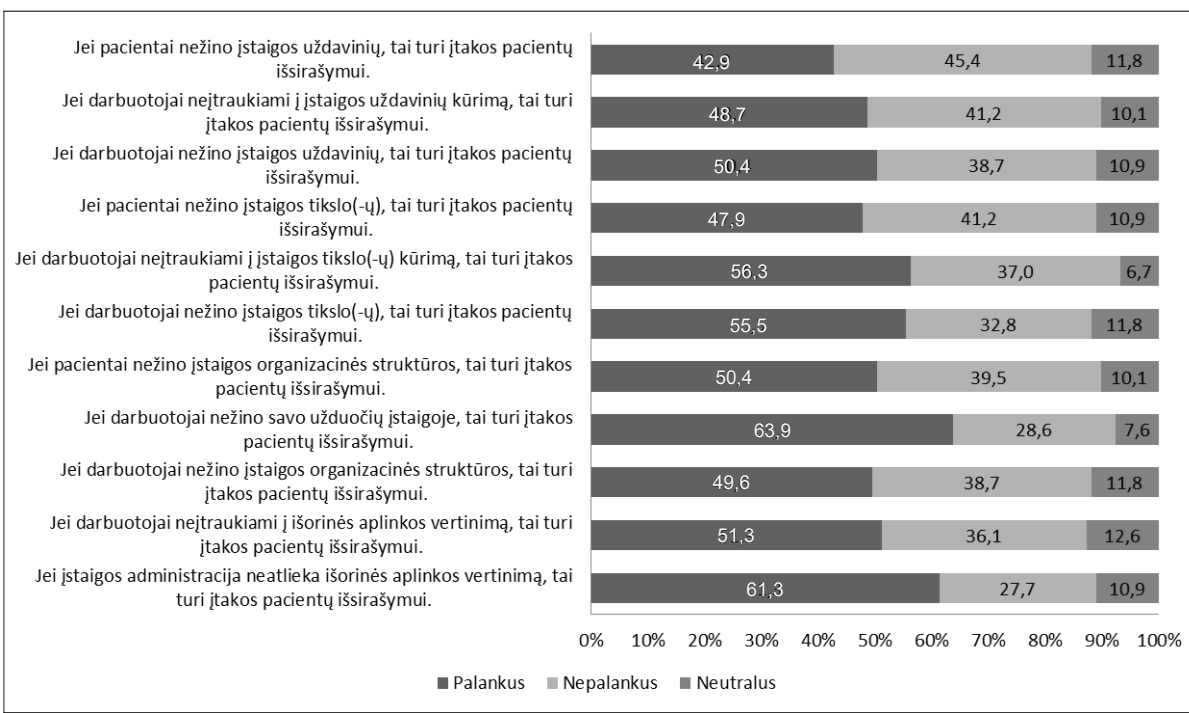

6 pav. Darbuotojų nuomonė apie tikslų, uždavinių, užduočių, organizacinės struktūros ir aplinkos vertinimo elementų itaką pacientų išsirašymui

išsiskyrè: valstybinès ịstaigos vadovas nurodè strategiją, o privačios - uždavinius. Vertinant sveikatos priežiūros įstaigų vadovų nuomonę, esminiai skirtumai išryškèjo dèl strateginių valdymo elementų paviešinimo: valstybinès įstaigos vadovo nuomone, svarbiausia paviešinti įstaigos tikslus, o privačios - viziją ir misiją, tačiau abu vadovai atsake, kad esamojoje situacijoje yra paviešinti įstaigų tikslai, kurie, jų nuomone, yra svarbūs pacientams.

Tyrimo metu nustatyta, kad pirminių sveikatos priežiūros įstaigų darbuotojai žino ìstaigos, kurioje dirba, strategiją. Kitų autorių atliktame tyrime taip pat buvo nustatyta, kad 62 proc. ịstaigų darbuotojų žino įstaigos strategiją [8]. Siekiant išvengti konfliktinių situacijų ir pacientų nepasitenkinimo, svarbu paviešinti ịstaigos misiją, viziją, uždavinius, tikslus ir stiprybes, tai sudarys sąlygas pacientams neturèti nerealių lūkesčių, 
kurie neretai lemia pacientų nepasitenkinimą ir konfliktines situacijas [3].

\section{Išvados}

1. Sveikatos priežiūros įstaigų darbuotojų nuomone, didžiausios įtakos pacientų skaičiaus didejjimui turi įstaigos galimybių, stiprybių, tikslų, misijos ir vizijos paviešinimas, darbuotojų žinios apie įstaigos stiprybes, savo svarbos, realizuojant ịstaigos strategiją, suvokimas. Darbuotojų įstaigos stiprybių ir savo užduočių neišmanymas strategijos ịgyvendinimo kontekste, turi didžiausios įtakos pacientų skaičiaus mažèjimui.

2. Pacientų prisirašymui pirminèse sveikatos priežiūros ịstaigose didžiausios įtakos turi šeimos gydytojas.

3. Darbuotojų itraukimas ị ịstaigos strateginių valdymo elementų kūrimą gali paskatinti prisirašyti daugiau pacientų, nes darbuotojai, gerai išmanantys įstaigos siekius, komunikuoja juos pacientams.

\section{Literatūra}

1. Beattie SR, Osborne PS. Human resource management in the public sector. Routledge, New York 2008.

https://doi.org/10.4324/9780203824450

2. Chandler DA. Strategy and structure: chapter in the history of the industrial enterprise. Cambridge, Mass: MIT press; 1962.

3. Janušonis V. Sveikatos priežiūros organizacijų kokybės sistemų valdymas. Sveikatos mokslai, 2004;1:69-73.

4. Lietuvos Respublikos sveikatos sistemos įstatymas Nr. I-552. Vilnius, 1994. https://www.etar.lt/portal/lt/legalAct/TAR. E2B2957B9182

5. Liubarskienė Z., Šoliūnienė L., Kilius V., Peičius E. Pacientų pasitikejjimas ir sveikatos priežiūra. Medicina, 2004;40(3):278285.

6. Stoškus S., Beržinskienè D. Vadyba. Kaunas: KTU leidykla Technologija, 2005.

7. Šilys A. Vadovavimo kokybès vertinimas asmens sveikatos priežiūros ịstaigoje: Europos verslo tobulumo modelio ir $360^{\circ}$ grịžtamojo ryšio tyrimo taikymo ypatybès. Medicinos teorija ir praktika, 2009;15(2):170-177.

8. Išoraitė M. Žmogiškieji ištekliai - svarbiausias konkurencinio pranašumo šaltinis strategiškai valdant organizaciją. Socialinių mokslų studijos. 2011;3(1):31-58.
9. World health organization. Worl health report 2000. Health system: improving performance. Geneva, 2000.

\section{THE INTERFACES BETWEEN STRATEGIC MANAGEMENT ELEMENTS IN PRIMARY HEALTH CARE INSTITUTIONS STAFF ATTITUDE AND PERFORMANCE INDICATORS}

L. Šablinskas, G. Cibulskas

Keywords: primary health care institutions, health care staff, strategic management elements, performance indicators

Summary

Aim of the research: To evaluate the attitude of primary care workers on the links between strategic management elements and performance indicators.

Research methodology. The research was performed in 2016 by applying quantitative (questionnaire survey) and qualitative (semistructured interview method) research methods. Questionnaire survey was applied by questioning employees of two different types of primary health care facilities. Based on questionnaire results data the interview questions for heads of the same health care facilities were prepared. Statistical data analysis was prepared by using IBM SPSS 22.0 statistical analysis packet and graphs with tables were prepared by using Microsoft Excel 2010.

Results and conclusions. Assessing the opinion of health care workers and heads of health care facilities, it can be stated that the involvement of the institution's employees in the formation of the institution's strategic management elements, their awareness in the context of the institution's strategic goals has a significant impact on the number of primary health care patients decreasing or increasing. The clear refinement of staff tasks in the context of strategic aspirations, the sense of their importance in achieving strategic goals in the realization of the mission of the institution, also influences the indicators of decrease or increase in the number of patients in primary care institutions. According to employees and heads of health care facilities opinion, family doctors have the greatest influence on these performance indicators. Involving employees in the development of strategic management elements has a significant impact on the growth of the above mentioned performance indicators.

Correspondence to: lablinskas@gmail.com

Gauta 2020-06-29 